\title{
The Impact of Accounting Earnings on Stock Returns: The Case of Malaysia's Plantation Industry
}

\author{
Wong Pik $\operatorname{Har}^{1} \&$ Muhammad Afif. Abdul Ghafar ${ }^{2}$ \\ ${ }^{1}$ Faculty of Accountancy, Finance \& Business, Tunku Abdul Rahman College University, Malaysia \\ ${ }^{2}$ School of Business Management, University Tenaga Nasional, Selangor, Malaysia \\ Correspondence: Wong Pik Har, Faculty of Accountancy, Finance \& Business, Tunku Abdul Rahman College \\ University, Jalan Genting Kelang, 53300 Kuala Lumpur, Wilayah Persekutuan, Malaysia. Tel: 60-3-4145-0123. \\ E-mail: wongph@acd.tarc.edu.my
}

Received: February 9, 2015

Accepted: February 25, 2015

Online Published: March 27, 2015

doi:10.5539/ijbm.v10n4p155

URL: http://dx.doi.org/10.5539/ijbm.v10n4p155

\begin{abstract}
This study seeks to examine, (1) the effect of ROA, ROE and ROCE on stock return for plantation companies listed on the Main Board of Bursa Malaysia, in two distinct economic periods, prior to (2004-2006) and during (2007-2008) an economic recession and, (2) the resiliency of the plantation industry in Malaysia. Simple linear regression was used in analyzing the data. It was revealed that ROE had the highest explanatory power in explaining the variation in stock returns. ROA and ROCE were discovered to have a positive and significant relationship to stock returns only during the economic period prior to a recession. It was also discovered that the plantation industry in Malaysia is very resilient and is not adversely affected by an economic recession.
\end{abstract}

Keywords: accounting earnings, stock returns, plantation

\section{Introduction}

Financial result of a corporation attracts various people in the business world; investors, competitors, authorities, etc. Financial statements are analyzed from every possible angle to determine the 'health' of the company and subsequently, its attractiveness to investors. The main idea behind financial analysis is to determine exactly what position the company is in by obtaining key financial values that is an acceptable representation of the situation. Keef and Roush (2001) mentioned that the most informative performance financial measures are those that are able to reflect the profitability and capital aspect of the organization.

Agriculture remains an important sector of Malaysia's economy, contributing $12 \%$ to the national GDP and providing employment for $16 \%$ of the population. The three main crops are rubber, palm oil and cocoa. Based on the statistics obtained from the Malaysian Palm Oil Board (MPOB), in 2008 alone, the export for palm-oil and other palm-oil related products reached RM65.2 billion (MPOB). And according to the Malaysian Rubber Board (MRB), the production of natural rubber reached 1.2 million tonnes in 2007. However, despite of the huge importance of agriculture to the Malaysian economy, not a lot of research has been conducted in the plantation sector, in terms of the performance of companies in the agriculture industry and how the industry as a whole have performed in different economic conditions.

Given the aforementioned problems related to researches in the superiority of performances measures and its relation to the performance of firms in Malaysia's plantation industry in varying economic climates, this study seeks to address two issues. First, look at the impact of traditional accounting earnings (ROA, ROE and ROCE) on the stock return of companies in Malaysia's plantation industry. Second, whether the plantation industry in Malaysia is resilient or fragile.

We formulate and test hypotheses based on the issues stated above. It will seek to determine whether accounting earnings have a positive or negative impact on the stock prices of firms in Malaysia's plantation industry. It also aims to discover the resiliency of the plantation industry in Malaysia and whether the industry is highly influenced by different economic climates.

\section{Literature Review}

Accounting ratios provides the means for investors to compare the performance of the firm from one year to 
another, and also between other businesses within the same industry. Accounting ratios basically quantifies the business performance of a firm. By making comparisons of the ratios, investors can determine how efficient the firm is at utilizing their assets, paying off their debts, generating profits and making better investment decisions. From the perspective of the management team of the firm, accounting ratios support in the formulation of their business plans.

Accounting ratios can be classified into 4 distinct groups (profitability, liquidity, activity and leverage), with each group giving investor different view of the performance of a firm. Profitability ratios are used to assess how well a firm is at generating earnings over a specified period of time, i.e. quarterly or annually. Profitability ratios includes return on assets (ROA), return on Equity (ROE), return on capital employed (ROCE), earnings per share (EPS), etc.

Ball and Brown (1968) evaluated the usefulness of existing accounting income numbers from the aspect of their information content and timeliness. The evaluation on the usefulness of accounting practices has been assessed by accounting theorist to the scope in which the practice agrees with a particular analytic model. The model itself may be made up of a few statement or claims, or a well-developed argument. Either way the model are constructed, it possesses a particular shortcoming in which it ignores a large amount of information particularly, "to which the predictions of the model conform to observed behaviors" (Ball \& Brown, 1968). Furthermore, an analytical approach of evaluation raises the questions on what is possibility of one knowing that the theory is inclusive of all relevant supportable assumptions. Such limitations of a "completely analytical approach" to usefulness has been argued to the extent to which "income numbers cannot be defined substantively, that they lack "meaning" and are therefore of doubtful utility" (Ball \& Brown, 1968). The fact that accountants have to deal with new situations as it rises such as consolidations, leases, mergers, research and development, etc, shows the extent to which accounting lacks an "all-embracing theoretical framework" (Ball \& Brown, 1968), which resulted in dissimilarities in accounting practices. It is concluded in this paper that (a) information contained in an annual income number is useful and that it is related to the stock prices, (b) valuable information of a corporation is largely captured in the income number of the corporation.

It has been suggested traditional ratio analysis was no longer a useful analytical tool in the academic environment due to the "relatively unsophisticated manner in which it has been presented". Thus, Altman (1968) proved to analyze the quality of financial ratios. A set of financial and economic ratios were used from number of companies in bankruptcy prediction using multiple discriminant statistical methodology. The data used in the paper were that of manufacturing corporations. The motivation behind the paper was to bridge the gap between traditional ratio analysis and statistical techniques which have gained enormous popularity among academicians. The results obtained were encouraging as it had $94 \%$ accuracy in predicting bankruptcy correctly. Furthermore, it was found that by tracking the movements of the individual ratios, bankruptcy can be accurately predicted up to two years prior to failure.

Nissim and Penman (1999) outlined a financial statement analysis for use in equity valuation. The analysis is looked from the perspective of profitability and also growth. Current ratios are identified via analysis of current financial statements. The current ratios are used as predictors of the future ratios that drive equity payoffs. Values of documented ratios from period 1963-1996 are used in order to historical benchmarking purposes. The focus of the paper was split into two section which are (a) Identifying the ratios that are useful for valuation, (b) Documentation of the values of ratios from period 1963-1996. As quoted, “...ratio identification amounts to identifying ratios that reflect economic factors that determine - or drive - future residual income so that, by forecasting these ratios, the analyst builds a forecast of residual income" (Nissim and Penman, 1999). As mentioned earlier, profitability is also analyzed and standard profitability ratios are included in the analysis. Documentation of the ratios helps in the classification of financial statement items into "permanent" and "transitory". As for mentioned, documentation is crucial for benchmarking purposes and the historical analysis provides such benchmarks. As mentioned, Nissim and Penman has concluded ratios as the drivers of future residual earnings, free cash flow and dividends. From the current financial statement, the ratios are seen as a source of information to forecast future drivers.

Ohlson (1995) aimed at developing and analyzing the model of a firm's value with relation to future earnings, book values, and dividends. The model has shown that residual earnings are a variable that influences the value of a corporation. The performance measure is defined by "earnings minus a charge for the use of capital as measured by beginning-of-period book value multiplied by the cost of capital" (Ohlson, 1995). The model also acknowledges information beyond the realm of earnings, book value, and dividends. The additional information might be from value-relevant events that can have an impact future expected earnings as opposed to current earnings. This signifies that accounting measurement incorporate some value-relevant events only after a time 
delay. As a whole, the paper provides a benchmark model that can be utilized to conceptualize how value related to the variables of earnings, book value, and dividends. The model is able to satisfy number of properties in accounting such as, (a) "the theory rest directly on the clean surplus relation", (b) "the feature that dividends reduce book value but leave current earnings unaffected" (Ohlson, 1995).

Initial tests has shown the strong possibility of predicting markets returns using financial ratios like dividend yield, book-to-market and price/earning's ratios. Lewellen (2002) aimed at providing a new test of market predictability with emphasis on four points being, (a) Useful information that can be obtained when predictive variable's auto-correlation is close to the value of 1 , (b) The conditional test in this project paper are intuitive in nature, (c) Dividend yield have a much stronger forecasting power as compared to book-to-market and price/earnings ratio and, (d) The results are largely impacted by the data from the last few years of the study. It is concluded that dividend yield is good at predicting returns over data samples of longer periods. Book-to-market and price/earnings ratios are more suited at predicting shorter data samples.

Nichols and Wahlen (2004) used the three theoretical links developed by Beaver (1998) to understand the relation between earnings and returns. Beaver (1998) revealed that, (a) the current earnings of the company contained useful information for forecasting future earnings, (b) forecasts of future earnings provided important inputs in developing dividend expectations, and (c) the present value of expected future dividends determines share price. The results of the research was that, (a) annual stock returns are significantly related to the sign of the annual earnings, (b) persistence in earnings helped to explain the differences in the connection between stock returns and earnings, and (c) share prices are very elastic to the arrival of new information in quarterly earnings.

Despite of the extensive use of accounting earnings by financial analysts to determine the market value of a company, Rappaport (1981) stressed that earnings have a number of shortcomings and went on further to conclude that earnings fail to measure changes in the economic value of a firm. The first shortcoming was that company had the liberty to employ alternative accounting methods for financial reporting purposes. Because of this, management choices on which methods to use had a significant impact on earnings. The second shortcoming was that investment requirements, or specifically the investments required to sustain the working and fixed capital of a company is not taken into account in an earning's calculation. The third shortcoming was that earnings calculations do not take into account the time value of money. These shortcomings were also supported by Ehrbar (1998).

Traditional accounting measures refer to earnings per share (EPS), return on investment (ROI) and return on equity (ROE). Return on investment (ROI) or in a wider scope, the return on assets (ROA) is used as an indicator of how well the corporation is using the money that it has relative to its net income. Return on equity (ROE), on the other hand, measures a firm's efficiency at generating profits from every unit of shareholders' equity and it shows how well a company uses investment funds to generate earnings growth. Rappaport has explained that the traditional accounting measures such as ROI or ROA and ROE has its shortcomings and has mentioned in his book "Creating Shareholder's Value: A Guide for Managers and Investors" that "Earnings growth over a specified period of time is not only unreliably related to calculated increases in shareholder value, but it is unreliably related to total shareholder return (dividends plus change in share price)" (Rappaport, 2002). Rappaport also added that "With only a small percentage of investments capitalized for accounting purposes, ROI's and ROE's for knowledge-based companies such as Microsoft cannot be compared meaningfully with those of companies investing principally in fixed assets" (Rappaport, 2002). Furthermore, focus on earnings can lead to the manipulation of accounting policies for the purpose of earning maximization.

\section{Research Methodology}

Data on the share price of plantation-related companies listed on the main board of the Kuala Lumpur Composite Index (KLCI) were obtained directly from Bursa Saham located in Kuala Lumpur. All the companies that are selected for analysis consist of Main Board firms only, in periods covering from January 2004, up until December 2008.

The data are split into two distinct periods, pre-recession data (2004-2006), and recession data (2007-2008). Apart from selecting only plantation-related companies, the companies were also selected based on the criteria of consistency. This basically implies that company that is continuously listed on the Bursa Saham only will be included. The rationale behind this is that companies listed for a long period of time can provide better insight into the issues being investigated.

"Clean" data is most desirable but scrubbing it to the point of adversely affecting good analysis will ultimately defeats the purpose. As such, only extreme scores or outliers were removed from the sample. Outliers were determined using a stem and leaf plot and also a box plot. Based on the criteria listed above, a total of 25 
companies qualified as sample for this study.

\subsection{Variables and Measures}

The dependant variable for this research will be stock price/returns whereas the independent variables are accounting measures return on assets (ROA), return on equity (ROE), and return on capital employed (ROCE). Various studies have been conducted in the past that have consistently proven the powerful relationship between stock price/returns and accounting measures. We examine the relationship of the aforementioned accounting measures with stock return of plantation-related companies.

\subsection{Stock Returns}

The calculation of annual stock returns is the change in share prices in year ' $t$ ' plus dividend I year ' $t$ ' divided by closing share prices in year $\mathrm{t}-1$. The equation is as follows:

$$
R_{i t}=\frac{P_{i t}+D_{i t}+P_{i t-1}}{P_{i t-1}}
$$

Where:

$\mathrm{R}_{i t}=$ Return for share ' $\mathrm{i}$ ' in period ' $\mathrm{t}$ ';

$\mathrm{P}_{i t} \quad=$ Price of share ' $\mathrm{i}$ ' in period ' $\mathrm{t}$ ';

$\mathrm{D}_{i t}=$ Dividend of share ' $\mathrm{i}$ ' in period ' $\mathrm{t}$ ';

$\mathrm{P}_{i t-1}=$ Price of share ' $\mathrm{i}$ ' in period ' $\mathrm{t}$ '.

\subsection{Return on Assets (ROA)}

Return on assets indicates how profitable a company is relative to its total assets. It shows how profitable a company's assets are in generating income to the company. The equation is as follows:

$$
R O A=\frac{\text { Net Income }}{\text { Total Assets }}
$$

\subsection{Return on Equity (ROE)}

Return on equity is a profitability ratio that indicates how much profit a company is making with the money that has been invested by the shareholders. It is also a measure of efficiency of the company in generating earnings growth. The equation is as follows:

\subsection{Return on Capital Employed (ROCE)}

$$
\text { ROE }=\frac{\text { Net Income After Tax }}{\text { Shareholder Equity }}
$$

Return on capital employed informs how much profit is earned from the investments that the shareholders have made inside the company. It can also be used as a measure of efficiency of the company handling their capital investments. The equation is as follows:

$$
\text { ROCE }=\frac{\text { Earn before Interest \& Tax }}{\text { Total Assets }- \text { Total Liabilities }}
$$

\subsection{Model Specification}

Based on the results obtained from the correlation analysis, the strong correlation between the accounting ratios signifies that it is not suitable to use a multiple regression because the regression would produce high standard errors and as such it the determination of the explanatory power of each independent variables are difficult (refer to Tables 1\&2). 
Table 1. Result of correlation analysis for pre-recession data (2004-2006)

\begin{tabular}{|c|c|c|c|c|c|}
\hline \multicolumn{6}{|c|}{ Correlations } \\
\hline & & Stock Returns & $\begin{array}{c}\text { Return on } \\
\text { Assets } \\
\end{array}$ & $\begin{array}{l}\text { Return on } \\
\text { Equity }\end{array}$ & $\begin{array}{l}\text { Return on } \\
\text { Capital } \\
\text { Employed }\end{array}$ \\
\hline \multirow[t]{5}{*}{ Stock Returns } & Pearson Correlation & 1 & $.329^{-12}$ & $.432^{\mathrm{nn}}$ & $.412^{2 x}$ \\
\hline & Sig. (2-tailed) & & .006 & .000 & .000 \\
\hline & $\begin{array}{l}\text { Sum of Squares and } \\
\text { Cross-products }\end{array}$ & 170600.373 & 3706.219 & 6991.288 & 6943.748 \\
\hline & Covariance & 2508.829 & 54.503 & 102.813 & 102.114 \\
\hline & $\mathrm{N}$ & 69 & 69 & 69 & 69 \\
\hline \multirow[t]{5}{*}{ Return on Assets } & Pearson Correlation & $329^{\text {sin }}$ & 1 & $.857^{\mathrm{sx}}$ & $.832^{2 \times 1}$ \\
\hline & Sig. (2-tailed) & .006 & & .000 & .000 \\
\hline & $\begin{array}{l}\text { Sum of Squares and } \\
\text { Cross-products }\end{array}$ & 3706.219 & 745.251 & 917.326 & 928.451 \\
\hline & Covariance & 54.503 & 10.960 & 13.490 & 13.654 \\
\hline & N & 69 & 69 & 69 & 69 \\
\hline \multirow[t]{5}{*}{ Return on Equity } & Pearson Correlation & $432^{2 x}$ & $.857^{\mathrm{xx}}$ & 1 & $.845^{\mathrm{nx}}$ \\
\hline & Sig. (2-tailed) & .000 & .000 & & .000 \\
\hline & $\begin{array}{l}\text { Sum of Squares and } \\
\text { Cross-products }\end{array}$ & 6991.288 & 917.326 & 1538.333 & 1353.707 \\
\hline & Covariance & 102.813 & 13.490 & 22.623 & 19.907 \\
\hline & $\mathrm{N}$ & 69 & 69 & 69 & 69 \\
\hline \multirow{5}{*}{$\begin{array}{l}\text { Return on Capital } \\
\text { Employed }\end{array}$} & Pearson Correlation & $412^{\mathrm{sin}}$ & $832^{2 \mathrm{se}}$ & $845^{2 \mathrm{~m}}$ & 1 \\
\hline & Sig. (2-tailed) & .000 & .000 & .000 & \\
\hline & $\begin{array}{l}\text { Sum of Squares and } \\
\text { Cross-products }\end{array}$ & 6943.748 & 928.451 & 1353.707 & 1669.035 \\
\hline & Covariance & 102.114 & 13.654 & 19.907 & 24.545 \\
\hline & $N$ & 69 & 69 & 69 & 69 \\
\hline
\end{tabular}

*. Correlation is significant at the 0.01 level (2-tailed).

Table 2. Result of correlation analysis for pre-recession data (2007-2008)

\begin{tabular}{|c|c|c|c|c|c|}
\hline \multicolumn{6}{|c|}{ Correlations } \\
\hline & & Stock Returns & $\begin{array}{l}\text { Return on } \\
\text { Assets }\end{array}$ & $\begin{array}{c}\text { Return on } \\
\text { Equity }\end{array}$ & $\begin{array}{l}\text { Return on } \\
\text { Capital } \\
\text { Employed }\end{array}$ \\
\hline \multirow[t]{5}{*}{ Stock Returns } & Pearson Correlation & 1 & .249 & $.473^{x x}$ & .144 \\
\hline & Sig (2-tailed) & & .103 & .001 & .350 \\
\hline & $\begin{array}{l}\text { Sum of Squares and } \\
\text { Cross-products }\end{array}$ & 769096.864 & 6213.800 & 17287.259 & 10288.333 \\
\hline & Covariance & 17885.974 & 144.507 & 402.029 & 239.264 \\
\hline & $\mathrm{N}$ & 44 & 44 & 44 & 44 \\
\hline \multirow[t]{5}{*}{ Return on Assets } & Pearson Correlation & .249 & 1 & $.791^{2 x}$ & $.464^{x-2}$ \\
\hline & Sig (2-tailed) & .103 & & .000 & .002 \\
\hline & $\begin{array}{l}\text { Sum of Squares and } \\
\text { Cross-products }\end{array}$ & 6213.800 & 809.953 & 937.800 & 1073.242 \\
\hline & Covariance & 144.507 & 18.836 & 21.809 & 24.959 \\
\hline & $\mathrm{N}$ & 44 & 44 & 44 & 44 \\
\hline \multirow[t]{5}{*}{ Return on Equity } & Pearson Correlation & $.473^{x \times}$ & $.791^{\mathrm{nx}}$ & 1 & $.586^{x 2}$ \\
\hline & Sig (2-tailed) & .001 & .000 & & .000 \\
\hline & $\begin{array}{l}\text { Sum of Squares and } \\
\text { Cross-products }\end{array}$ & 17287.259 & 937.800 & 1736.100 & $1986.28 i$ \\
\hline & Covariance & 402.029 & 21.809 & 40.374 & 46.193 \\
\hline & $\mathrm{N}$ & 44 & 44 & 44 & 44 \\
\hline \multirow{5}{*}{$\begin{array}{l}\text { Return on Capital } \\
\text { Employed }\end{array}$} & Pearson Correlation & .144 & $.464^{\pi x}$ & $.586^{x x}$ & 1 \\
\hline & Sig (2-tailed) & .350 & .002 & .000 & \\
\hline & $\begin{array}{l}\text { Sum of Squares and } \\
\text { Cross-products }\end{array}$ & 10288.333 & 1073.242 & 1986.287 & 6617.194 \\
\hline & Covariance & 239.264 & 24.959 & 46.193 & 153.888 \\
\hline & $\mathrm{N}$ & 44 & 44 & 44 & 44 \\
\hline
\end{tabular}

As such, this thesis will employ the use of a simple regression to solve the issue of multicollinearity. The regression equations for both period (pre-recession and recession) are as shown below:

$$
\begin{aligned}
& \operatorname{Re} t=\beta_{0}+\beta_{1} R O A+\varepsilon \\
& \operatorname{Re} t=\beta_{0}+\beta_{1} R O E+\varepsilon \\
& \operatorname{Re} t=\beta_{0}+\beta_{1} R O C E+\varepsilon
\end{aligned}
$$

Where:

Ret $=$ Stock Return;

$\mathrm{ROA}=$ Net Income/Total Assets; 
ROE = Net Income after Tax / Shareholder Equity;

ROCE $=$ Earnings Before Interest and Tax / (Total Assets-Total Liabilities).

\subsection{Research Hypothesis}

The research hypotheses of the study are as follows:

Hypothesis $\mathrm{H}_{\mathrm{o}}$ : ROA has a positive influence on stock return.

Hypothesis $\mathrm{H}_{0} 2$ : ROE has a positive influence on stock return.

Hypothesis $\mathrm{H}_{\mathrm{o}} 3$ : ROCE has a positive influence on stock return.

\section{Result of Analysis}

\subsection{Descriptive Statistics of Variables}

During the pre-recession period 2004-2006, stock returns indicated a mean of $(\mathrm{M})=33.79 \%$ and standard deviation of $(\mathrm{SD})=50.09 \%$. During the recession period $2007-2008$, however, reveals a huge improvement in the average stocks returns as compared to the pre-recession period, with $(\mathrm{M})=150.78 \%$ and $(\mathrm{SD})=133.74 \%$. A similar trend can also be observed for the accounting ratios in which there is a substantial improvement in the performance of the plantation firms, despite of period of recession, as presented in Table 3 and 4.

Table 3. Descriptive statistics of variables (Pre-Recession, 2004-2006)

\begin{tabular}{lll}
\hline Variables & Mean (\%) & Standard Deviation (\%) \\
\hline Stock Returns & 33.79 & 50.09 \\
Return on Assets (ROA) & 5.72 & 3.31 \\
Return on Equity (ROE) & 8.18 & 4.76 \\
Return on Capital Employed (ROCE) & 9.12 & 4.95 \\
\hline
\end{tabular}

Table 4. Descriptive statistics of variables (Recession, 2007-2008)

\begin{tabular}{lll}
\hline Variables & Mean (\%) & Standard Deviation (\%) \\
\hline Stock Returns & 150.78 & 133.74 \\
Return on Assets (ROA) & 10.27 & 4.34 \\
Return on Equity (ROE) & 14.90 & 6.35 \\
Return on Capital Employed (ROCE) & 23.67 & 12.41 \\
\hline
\end{tabular}

The overall descriptive statistics supports the statement that the plantation sector in Malaysia is very resilient and companies in the sector are not adversely affected by an economic recession.

\subsection{Correlation Analysis}

Before the research hypotheses were derived, the accounting ratios were tested for multi-collinearity. Multi-collinearity occurs in regression when there is a stronger correlation between among the independent variables rather than with the dependent variables, in this case the stock return. As one of the purpose of this study is not only to determine whether there is a relationship between stock return and the accounting ratios, but also the level of explanatory power of each accounting ratios, multi-co linearity must first be addressed in order to prevent the inflation of the variances of the parameter estimates, and only then can a the correct conclusions be made about the relationships between the stock returns and accounting ratios.

Table 3 and 4 above shows that there are substantial evidence to prove that there exist a relatively high level of correlation between the set of predictors or accounting ratios (i.e., ROA, ROE and ROCE) and stock returns during the pre-recession and recession periods. This further supports the utilization of simple linear regression as opposed to multiples regression technique for this study.

\subsection{Results of Accounting Measures on Stock Returns}

The multi-collinearity analysis indicates that there is a relatively high level of relations between the variables. However, the analyses still have not shown the influence of the accounting measures on stock returns. As such, this study will employ the use of simple regression technique in the periods prior to recession (2004-2006) and during recession (2007-2008) in order to address the said issues. 


\subsection{Impact of Accounting Measures on Stock Returns (Pre-Recession, 2004-2006)}

From Table 5, the null hypothesis is rejected at the $1 \%$ level $(\mathrm{p}<0.01)$ for the simple regression analysis between ROA and stock returns. With the rejection of the null hypothesis, the positive relationship between ROA and stock returns is confirmed with a positive beta $(\beta)=0.329$. It is also shown that the explanatory power (R2) of the variable ROA on the variation of stock return. It is discovered that $10.8 \%$ of the variance in stock returns is explained by the variance in ROA.

Table 5. Impact of accounting measures (ROA, ROE and ROCE) on stock returns prior to recession (2004-2006)

\begin{tabular}{lllll}
\hline Predictor Variables & $\begin{array}{l}\text { Regression } \\
\text { Equation }\end{array}$ & Standard Coefficients ( $\boldsymbol{\beta})$ & p-value & $\mathbf{R}^{\mathbf{2}}$ \\
\hline Return on Assets (ROA) & Ret $=\beta_{0}+\beta_{1} \mathrm{ROA}+\varepsilon$ & 0.329 & $<0.01$ & 0.108 \\
Return on Equity (ROE) & Ret $=\beta_{0}+\beta_{1} \mathrm{ROE}+\varepsilon$ & 0.432 & $<0.01$ & 0.186 \\
Return on Capital Employed (ROCE) & Ret $=\beta_{0}+\beta_{1} \mathrm{ROCE}+\varepsilon$ & 0.412 & $<0.01$ & 0.169 \\
\hline
\end{tabular}

The null hypothesis is also rejected for the simple regression analysis between ROE and stock returns $(\mathrm{p}<0.01)$. Similar to ROA, ROE also exhibits a positive relationship against stock returns with $\beta=0.432$. ROE explains the variance in stock returns more than ROA with a value of $18.6 \%$.

The null hypothesis is also rejected for the simple regression analysis between ROCE and stock returns $(\mathrm{p}<0.01)$. A positive relationship is evident between stock returns and ROCE with $\beta=0.412$. It is discovered that $16.9 \%$ of the variance in stock returns is explained by the variance in ROCE, which is higher than ROA but lower as compared to ROE.

\subsection{Impact of Accounting Measures on Stock Returns (Recession, 2004-2006)}

It is discovered, that during the recession period, ROA and ROCE did not have any explanatory power in the variation of stock returns with $\mathrm{p}>0.01$ (Table 6). ROE, however, was significant in explaining the variation in stock returns. A positive relationship is evident between stock returns and ROE with $\beta=0.473$. It is also evident from the analysis that $22.4 \%$ of the variance in stock returns is explained by the variance in ROE, which is almost a $4 \%$ increase from the data obtained during the pre-recession period.

Table 6. Impact of accounting measures (ROA, ROE and ROCE) on stock returns during recession (2007-2008)

\begin{tabular}{lllll}
\hline Predictor Variables & $\begin{array}{l}\text { Regression } \\
\text { Equation }\end{array}$ & Standard Coefficients ( $\beta$ ) & p-value & $\mathbf{R}^{2}$ \\
\hline Return on Assets (ROA) & Ret $=\beta_{0}+\beta_{1}$ ROA $+\varepsilon$ & 0.249 & $>0.01$ & 0.062 \\
Return on Equity (ROE) & Ret $=\beta_{0}+\beta_{1}$ ROE $+\varepsilon$ & 0.473 & $<0.01$ & 0.224 \\
Return on Capital Employed (ROCE) & Ret $=\beta_{0}+\beta_{1}$ ROCE $+\varepsilon$ & 0.114 & $>0.01$ & 0.350 \\
\hline
\end{tabular}

Summary of the Results of Hypotheses and Major Findings:

1) ROE have a positive influence on stock returns during the pre-recession and recession period.

2) ROA and ROCE have exhibited a positive influence on stock returns only during the pre-recession period.

3) During the pre-recession period, ROE have the highest explanatory power on the variation of stock returns, followed by ROCE. ROA have the least explanatory power on the variation of stock returns.

\section{Discussion}

Ever since the breakthrough studies of Ball and Brown (1968) on the relationships between accounting earnings and stock returns, numerous studies have been conducted within the framework of independent variables constituting of accounting ratios and stock returns as the dependent variables. Research on the relationships between stock returns and accounting earnings thereafter expanded on the ability to forecast future earnings from stock movements.

Analysts evaluate the quality of reported earnings, for example, with the hope of making better forecasts of future earnings. However, Lev (1989) in his study concluded that explanatory power of earnings for stock returns was low, and as such, the usefulness of earnings published by companies was also low. In another study conducted (Penman \& Zhang, 1999), it was also concluded that the stock market did not appear to price lower 
quality earnings appropriately. This implied that the ability of the earnings disclosure to accurately price a company's worth via their stock returns and truly reflect the performance of the company was low. The results from this study further prove that the explanatory power of accounting ratios in explaining the variation of stock returns is low.

A number of explanations have been given to explain for the given phenomenon (Strong \& Walker, 1993) which included, (1) the availability of time and relevant information in financial statements (Beaver et al., 1980), and (2) questionable qualities of reported earnings due to differences in accounting practices and /or systematic abuse of the earnings management process. The first point stresses on the fact that earnings recorded in the financial statements represents the 'economic history' of an enterprise implies that accounting earnings measure different economic constructs (Lee, 1999). More importantly, the study of historical financial statements is simply not sufficient for making projection about a company's performance. Other factors such macroeconomic factors like interest rates and inflation must also be taken into account.

Another plausible reason for the phenomenon is investor's psychology. This basically implies that investor's reaction a particular firm is very much psychological in nature, i.e. news of an impending economic recession will trigger investors to sell of their stocks, thus, driving down the stock price of the firm in which they have invested in. This statement can be further supported by a study conducted by De Bondt and Thaler (1985), in which it was discovered that "people systematically overreacting to unexpected and dramatic news event results in substantial weak-form inefficiencies in the stock market".

\subsection{Performance of Plantation Industry in Malaysia}

From descriptive statistics of the variable, it was proven that the plantation industry is very resilient and its performance is not largely influenced by an economic recession. The average value of stock returns increased by a factor of 3 , from $50 \%$ during the pre-recession period to $150 \%$ during the recession period. Similar trend was also observed for the accounting ratios ROA, ROE and ROCE.

This trend is further supported with the statistics for palm-oil and palm-oil related products in which exports reached a record of RM65.2 billion in the year 2008, which was a $44.3 \%$ increase, compared with RM45.1 billion in 2007. In March 2008, the price of palm oil reaches a historical high of RM4,486 (MPOC). In the rubber industry, the production of natural rubber in 2007 reached 1.2 million tones (Table 7). The price of latex also increased steadily from 2004 onwards and reached a peak of RM9.51 in 2008 (Table 8).

Historical data have shown that the demand for palm oil is always increasing despite of the up and downs of the global economic cycle (refer Figure 1 \& 2).

Table 7. Annual rubber production in Malaysia (1998-2009)

\begin{tabular}{|c|c|c|c|c|c|c|}
\hline \multicolumn{7}{|c|}{ ('000 tonnes) } \\
\hline \multirow{3}{*}{ Year } & \multicolumn{2}{|c|}{ Estate } & \multicolumn{2}{|c|}{ Smallholding } & \multirow{3}{*}{$\begin{array}{l}\text { Total } \\
\text { Production } \\
\text { (tonnes) }\end{array}$} & \multirow{3}{*}{$\begin{array}{c}\text { Average } \\
\text { Yield } \\
\text { (Kg/Ha/Yr }\end{array}$} \\
\hline & Production & Yield & Production & Yield & & \\
\hline & (tonnes) & $(\mathrm{Kg} / \mathrm{Ha} / \mathrm{Yr})$ & (tonnes) & $(\mathrm{Kg} / \mathrm{Ha} / \mathrm{Yr})$ & & \\
\hline 1998 & 198.87 & 1,330 & 686.83 & 906 & 885.70 & 970 \\
\hline 1999 & 183.06 & 1,447 & 585.81 & 876 & 768.87 & 960 \\
\hline 2000 & 128.13 & 1,289 & 799.47 & 1,184 & 927.61 & 1,226 \\
\hline 2001 & 99.53 & 1,358 & 782.53 & 1,167 & 882.07 & 1,211 \\
\hline 2002 & 84.88 & 1,361 & 804.95 & 1,211 & 889.83 & 1,237 \\
\hline 2003 & 76.36 & 1,344 & 909.29 & 1,270 & 985.65 & 1,280 \\
\hline 2004 & 71.23 & 1,372 & $1,097.50$ & 1,296 & $1,168.74$ & 1,300 \\
\hline 2005 & 65.29 & 1,381 & $1,060.73$ & 1,320 & $1,126.02$ & 1,320 \\
\hline 2006 & 68.40 & 1,525 & $1,215.23$ & 1,358 & $1,283.63$ & 1,370 \\
\hline 2007 & 66.80 & 1,520 & $1,132.80$ & 1,414 & $1,199.55$ & 1,420 \\
\hline 2008 & 59.59 & 1,600 & $1,012.77$ & 1,420 & $1,072.36$ & 1,430 \\
\hline $2009^{*}$ & 41.98 & $1,610^{e}$ & 576.40 & $1,440^{e}$ & 618.38 & $1,450 *$ \\
\hline Note: & \multicolumn{6}{|c|}{$\begin{array}{l}\text { *January - September } \\
\text { e estimate }\end{array}$} \\
\hline Source: & \multicolumn{6}{|c|}{ Department of Statistics, Malaysia; Malaysian Rubber Board (MRB) } \\
\hline
\end{tabular}


Table 8. Rubber prices in Malaysia (1998-2009)

\begin{tabular}{|c|c|c|c|c|c|c|c|c|c|c|c|c|}
\hline Year & RSS 1 & RSS 2 & RSS 3 & RSS 4 & RSS 5 & $\begin{array}{l}\text { SMR } \\
\text { CV }\end{array}$ & SMR L & SMR 5 & $\begin{array}{c}\text { SMR } \\
10\end{array}$ & $\begin{array}{c}\text { SMR } \\
20\end{array}$ & $\begin{array}{l}\text { SMR } \\
\text { GP }\end{array}$ & $\begin{array}{c}\text { Bulk } \\
\text { Latex(dry) }\end{array}$ \\
\hline 1998 & 280.54 & 273.19 & 272.69 & 262.27 & 257.27 & 359.87 & 308.97 & 274.28 & 261.06 & 259.00 & 270.06 & 373.72 \\
\hline 1999 & 239.26 & 232.09 & 230.59 & 220.05 & 215.05 & 274.98 & 253.71 & 235.82 & 228.91 & 226.94 & 237.91 & 299.68 \\
\hline 2000 & 261.93 & 253.66 & 252.16 & 241.66 & 236.66 & 330.01 & 295.37 & 252.88 & 244.52 & 242.52 & 253.52 & 337.54 \\
\hline 2001 & 227.30 & 219.92 & 218.42 & 207.92 & 202.92 & 269.16 & 254.02 & 213.59 & 207.56 & 205.56 & 216.56 & 283.42 \\
\hline 2002 & 293.26 & 289.30 & 287.80 & 277.30 & 272.30 & 347.05 & 336.41 & 292.13 & 288.00 & 285.98 & 297.00 & 343.90 \\
\hline 2003 & 400.64 & $\cdot$ & $\cdot$ & $\cdot$ & $\cdot$ & 472.89 & 449.89 & 387.97 & 380.97 & 378.97 & 389.67 & 479.54 \\
\hline 2004 & $\cdot$ & $\cdot$ & $\cdot$ & $\cdot$ & $\cdot$ & 556.03 & 526.60 & 481.41 & 463.93 & 461.93 & 472.93 & 551.31 \\
\hline 2005 & $\cdot$ & $\cdot$ & - & $\cdot$ & - & 627.30 & 593.67 & 536.79 & 525.07 & 523.07 & 534.07 & 634.68 \\
\hline 2006 & $\cdot$ & $\cdot$ & $\cdot$ & $\cdot$ & $\cdot$ & 851.48 & 795.26 & 724.92 & 712.92 & 710.92 & 721.92 & 851.68 \\
\hline 2007 & - & - & - & - & - & 857.30 & 792.17 & 748.06 & 736.06 & 734.06 & 745.06 & 854.18 \\
\hline 2008 & - & $\cdot$ & - & - & $\cdot$ & 958.75 & 935.20 & 845.37 & 833.37 & 831.37 & 842.37 & 951.51 \\
\hline 2009 & - & - & - & - & - & 707.09 & 677.28 & 655.72 & 639.36 & 637.36 & 652.72 & 745.87 \\
\hline $\begin{array}{l}\text { Note: } \\
\text { Souro }\end{array}$ & $\begin{array}{l}\text { Quota } \\
\text { Quota } \\
\text { e: Malay }\end{array}$ & n Rub & Board & $\begin{array}{l}\text { from } \\
\text { RB) }\end{array}$ & $\begin{array}{l}55 \mathrm{~s} \\
004\end{array}$ & d f mo & 3003 & & & & & \\
\hline
\end{tabular}

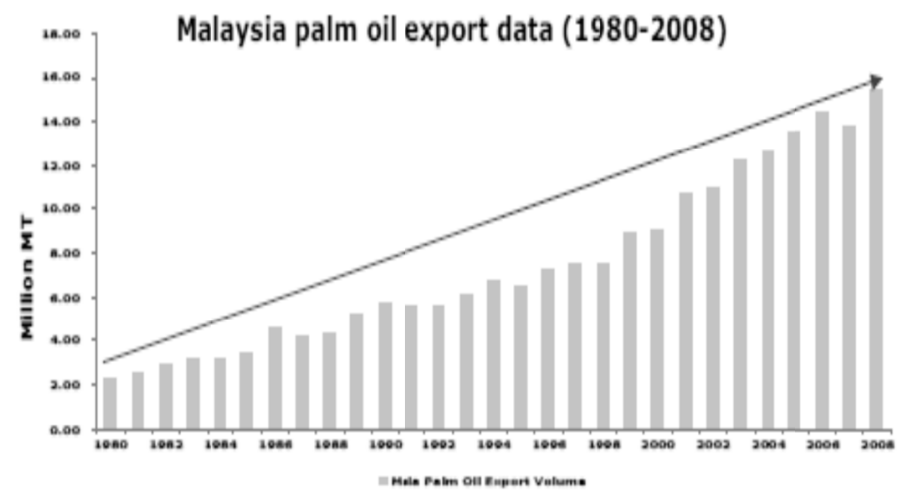

Figure 1. Export volume and value of palm oil products

Source: malaysia palm oil board.

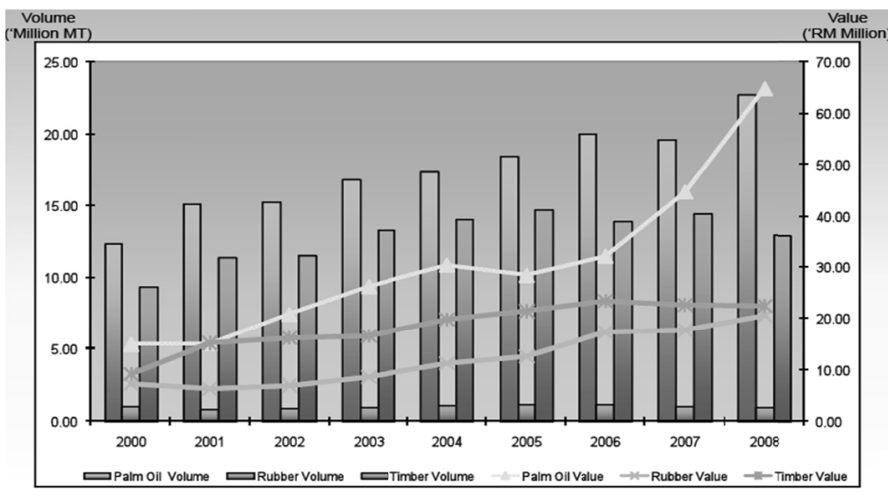

Figure 2. Export volume and value of selected primary commodities \& commodity-based products Source: Malaysia Palm Oil Board.

The underlying reason behind this might be due to the simple fact that palm oil is considered as a necessity, particular as an important source of food. Furthermore, the use of palm oil is spread to not only for human consumption but also oleochemicals for the production of various household products such as bar soap, shampoo, 
etc, and also an alternative source of fuel in the form of bio-diesel. All in all, the future of palm oil is essentially driven due to economic and population growth.

\subsection{Limitations and Directions for Future Research}

The findings from this study suggest that there needs to be shift in the approach of the research. It might be more beneficial for future research to focus on the relationship between current accounting earnings to future stock returns rather than simply relating accounting earnings to current stock returns. Furthermore, these research needs to expand the study beyond that of accounting earnings and book value and involve external sources of information as mentioned in the earlier sections, which includes market conditions, macroeconomic factors, non-financial information, etc.

Such research can lead to a better understanding of the underlying motivation behind the variation of stock returns and subsequently have a greater impact not only on the scope of accounting research but also on its practical implementation by investors and practitioners.

\section{Conclusion}

In general, ROE was found to the best performer as compared to the rest of the performance measures (ROA and ROCE) in predicting stock returns. ROE was able to explain the variation in stock return during both economic periods. The impact of ROA and ROCE on the variation of stock return, however, was only evident during the pre-recession period (2004-2006). During the pre-recession period, all of the performance measure was found to have a positive relationship to stock returns. Finally, the descriptive statistics showed that the plantation industry in Malaysia is very resilient and not adversely affected by an economic recession.

\section{References}

Altman, E. I. (1968). Financial Ratios, Discriminant Analysis and the Prediction of Corporate Bankruptcy. Journal of Finance, 589-609. http://dx.doi.org/10.1111/j.1540-6261.1968.tb00843.x

Ball, R., \& Brown, P. (1968). An Empirical Evaluation of Accounting Income Numbers. Journal of Accounting Research, 6(2), 159-178. http://dx.doi.org/10.2307/2490232

Beaver, W. (1998). Financial Reporting: An Accounting Revolution (3rd ed.). Prentice Hall. http://dx.doi.org/10.1016/0165-4101(80)90013-0

Beaver, W. H., \& Lambert, R. A. (1980). The Information Content of Security Prices. Journal of Accounting and Economics, 2, 3-28.

Berle, A., \& Means G. (1932). The Modern Corporation and Private Property (1st ed.). Transaction Publishing. http://dx.doi.org/10.1016/0304-405X(76)90026-X

Chen, S., \& Dodd, J. L. (2001). Operating Income, Residual Income and EVA: Which Metric is More Value Relevant? Journal of Managerial Issues, 13(1), 65-86.

De Bondt, Werner, F. M., \& Richard, T. (1985). Does the Stock Market Overreact? The Journal of Finance, 40(3), 793-805. http://dx.doi.org/10.1111/j.1540-6261.1985.tb05004.x

Ehrbar, A. (1998). EVA: The Real Key to Creating Wealth (1st ed.). John Wiley \& Sons Inc.

Ittner, C. D., \& Larcker, D. F. (1998). Innovations in Performance Measurement: Trends and Research Implications. Journal of Management Accounting Research, (10), 205-238.

Jensen, M. C., \& Meckling, W. H. (1976). Theory of the Firm: Managerial Behaviour, Agency Costs and Ownership Structure. Journal of Financial Economics, 3, 305-360.

Keef, S., \& Roush, M. (2001). Residual Income: A Review Essay. Australian Accounting Review, 11(1), 8-14. http://dx.doi.org/10.1111/j.1835-2561.2001.tb00175.x

Lee, M. (1999). Accounting-Based Valuation: Impact on Business Practices and Research. Accounting Horizons, 13(4), 413-425. http://dx.doi.org/10.2308/acch.1999.13.4.413

Lev, B. (1989). On the Usefulness of Earnings and Earnings Research: Lessons and Directions from Two Decades of Empirical Research. Journal of Accounting Research, 27, 153-201. http://dx.doi.org/10.2307/2491070

Lewellen, J. W. (2002). Predicting Returns with Financial Ratios. MIT Sloan Working Paper, No. 4374-02.

Nichols, D. C., \& Wahlen, J. M. (2004). How Do Earnings Numbers Relate to Stock Returns? A Review of Classis Accounting Research with Updated Evidence. Accounting Horizons, 18(4), 263-286. 
http://dx.doi.org/10.2308/acch.2004.18.4.263

Nissim, D., \& Stephen, H. P. (1999). Ratio Analysis and Equity Valuation. Berkeley: Working Paper, The Walter A. Haas School of Business, University of California.

Ohlson, J. (1995). Earnings, Book Values, and Dividends in Equity Valuation. Contemporary Accounting Research, 11(2), 661-687. http://dx.doi.org/10.1111/j.1911-3846.1995.tb00461.x

Penman, S., \& Zhang, X. J. (1999). Conservatism, Growth and Accounting Rates of Return: An Empirical Analysis. Working Paper, University of California, Berkeley.

Rappaport, A. (1981). Selecting Strategies That Create Shareholder Value. Harvard Business Review, 59(3), 139-149.

Strong, N., \& Walker, M. (1993). The Explanatory Power of Earnings and Stock Returns. The Accounting Review, 68(2), 385-399.

Yang, D., Wang, F., \& Du, X. L. (2006). Empirical Research on Accounting Profits and Net Cash Flow of Chinese Public Companies: Analysis Based on Profitability. Journal of Modern Accounting and Auditing, 2(4).

\section{Copyrights}

Copyright for this article is retained by the author(s), with first publication rights granted to the journal.

This is an open-access article distributed under the terms and conditions of the Creative Commons Attribution license (http://creativecommons.org/licenses/by/3.0/). 